\author{
AMERICAN JOURNAL OF FOOD AND NUTRITION \\ Print: ISSN 2157-0167, Online: ISSN 2157-1317, doi:10.5251/ajfn.2012.2.2.42.46 \\ (C) 2012, ScienceHuß, http://www.scihub.org/AJFN
}

\title{
Acute toxicity of synyhetic resin effluent to African Catfish, Clarias gariepinus [BURCHELL, 1822].
}

\author{
Dahunsi, S.O*, Oranusi, S.U. \\ ${ }^{1}$ Biological Sciences Department, Covenant University, Ota, Ogun State, Nigeria. \\ *Corresponding author: Phone :+2347032511675; dahunsi_olatunde@yahoo.com.
}

\begin{abstract}
Aquatic pollution as a field has gained a lot of attention over the decades majorly because of the vital role the aquatic environment plays in the human lifecycle. Indusrial wastewaters are often generated and discharged into the environment without treatment. Toxicity of effluents from Synythetic Resin production plant were evaluated in this study. Acute toxicity (96-h $\mathrm{LC}_{50}$ ) was evaluated using $0.23,0.31,0.35$ and $0.39 \mathrm{mg} / \mathrm{L}$ of the effluent in a renewal bioassay procedure. Physicochemical parameters of the effluent were also evaluated, the values obtained for lead, cyanide, total suspened solid, total hadness, total dissolved solids and alkalinity were higher than the Federal Environmental Protection Agency standard specification for effluent discharge into aquatic environment and as such contributed to the effluent's toxicity. Mortality increased as the concentrations of the effluent increases and $0.355 \mathrm{mg} / \mathrm{L}$ was obtained as $\mathrm{LC}_{50}$. The research eventually revealed that the synthetic resin effluent has a high level of toxicity to catfish. Deleterious effects such as biomagnification and other abberations may occur in man if exposed to substantial concentration of the effluent.
\end{abstract}

Keywords: Aquatic pollution, Clarias gariepinus, effluent, lethal concentration, toxicity.

\section{INTRODUCTION}

Water pollution is the contamination of water bodies such as lakes, rivers, oceans and groundwater by human activities. All water pollution affects organisms and plants that lives in these water bodies and in almost all cases, the effect is damaging not only to the individual specie and populations, but also to the natural biological communities. It occurs when pollutants are discharged directly or indirectly into water bodies without adequate treatment to remove harmful constituents (Agrawal et al., 2010). MartinSkilton et al., (2008) demonstrated that acute exposure of juvenile turbot, Scolphthalmus maximus to the prestige fuel oil elicits alterations in some hepatic biotransformation enzymes with different sensitivities and leads to decreased levels of testosterone in plasma of juvenile turbot which might threaten reproductive capability of exposed individuals. Akinbulumo, (2005) reported that fish showed toxic reactions to Derris elliptica root powder by surfacing jaws and becoming stupefied. Also, Mohsen et al., (2011) reported that two poisoning mechanisms may take place, one occuring at high concentrations and provoking a rapid suffocation by destruction of the gill epithelium, the other prevailing at low concentrations and consisting of an inhibition of the main metabolic pathways. Histological examination of Oreochromis niloticus gave significant indication of toxicity of Morinda lucida (Oyedapo and Akinduyite, 2011). Olufayo and Jatto, (2011) reported on the adverse effects of tobacco leaf dust on the blood of Oreochromis niloticus. Commercial petroleum fuel had a negative impact on the growth performance and survival of Nile Tilapia (Safaa and Mohsen, 2011). In juvenile turbot study, fish exposed to higher concentrations of commercial petroleum fuel exhibited reduced growth and feed consumption (Saborido-Ray et al., 2007).

Kavitha et al., (2011) observed that Moringa oleifera seed extract was toxic to fish, Cyprinus carpio at higher concentrations. Akhila et al., (2007) reported that the determination of acute toxicity is usually an initial screening step in the assessment and evaluation of the toxic characteristics of all compounds. Mahabub-uz-zaman et al., (2008) discovered a high lipid peroxide level in fishes exposed to textile mill effluent, they opined that if these fishes are consumed by man, they may cause physiological problems and as such investigations are of considerable significance specificaly in third world countries where consumers remain unaware of the quality of fish sold in the local markets. The 
purpose of fish acute toxicity is for decision whether a certain xenobiotic is dangerous for the environment. Acute toxicity tests are short term tests designed to measure the effect of toxic agents on aquatic species during a short period of their life span (Ebrahimpour et al., 2010)

The objectives of this study therefore is to investigate the toxicity of synthetic resin effluent to the African catfish, Clarias gariepinus.

\section{MATERIALS AND METHODS}

Test Chemical:- The effluent used for this reseach was obtained from a factory in Sango-Ota Industrial Estate, producing synthetic resin, chemical additives and emulsions. The effluent was collected in batches over a period of time and then pooled together to avoid variability in concentration and was refrigerated immediately to prevent further microbial growth.

Test Organism:- Clarias gariepinus weighing between 0.4 to $0.5 \mathrm{~kg}$ were employed for this test since variability in size may lead to different responses to the effluent of the same concentration. They were procured from a commercial Agricultural farm in Ogbomoso, Oyo State. The test organisms were kept in a large plastic container that has already been washed and rinsed with $5 \%$ potassium trioxonitrate to remove any adhered metals and thereafter acclimatized for a period of fourteen days. During this period of acclimatization, renewal bioassay was employed and fishes were fed twice daily (12 hourly) with already formulated fish feed with about $40 \%$ crude protein content. Aerators were employed for proper oxygen dissolution during the exposure period.

Physicochemical Analysis:- The physicochemical analysis of the effluent was carried out prior to the laboratory experiment to quantify the concentrations of the metals and other parameters in the effluent of study using the APHA/AWWA/WEF (1999) Standard method for examination of water and waste waters.

Acute Toxicity Test:- After the acclimatization period, range finding test was carried out to determine the definitive concentrations to be used for the acute evaluation test. This is in agreement with Rand, (2008) who reported that that range finding acute test is conducted to pin point exposure concentrations, the definitive acute test is first conducted to estimate $\mathrm{LC}_{50}$ of the chemical to which the organisms are exposed. Five plastic bowls were labeled $A-E$ with each having a replicate and the test solution (effluent) was thoroughly mixed by pouring into a big plastic bowl before exposing the test organism in the labeled plastic bowl. The varying concentrations used were $A=0.00 \mathrm{mg} / \mathrm{L}$ serving as control, $B=0.23 \mathrm{mg} / \mathrm{L}, C=0.31 \mathrm{mg} / \mathrm{L}, \mathrm{D}=0.35 \mathrm{mg} / \mathrm{L}$ and $\mathrm{E}=0.39 \mathrm{mg} / \mathrm{L}$ respectively. The experiment was monitored for 96hours to determine the $L_{50}$. Mortalities were recorded at intervals and the following were determined;

a. Total number of death (mortality) after 96 hours

b. The percentage mortality at 96 hours

c. The $L_{50}$ which is the concentration at which half or $50 \%$ of the test organism died on exposure

Since the organisms were exposed for 96 hours, the 96-h LC $_{50}$ was determined from the graph of percentage mortality against concentration. Arithmetic Graphic method was used to determine the 96-h LC 50 .

\section{RESULTS AND DISCUSSION}

Result:-

Physicochemical Characteristics of Synthetic Resin Effluent:- This is shown in (Table 1). The data obtained have some of its values conforming to FEPA, (1991) specifications for maximum limits allowed for effluent discharge into water bodies while the values for lead, cyanide, total hardness, oil and grease do not conform to the standard.

Table 1:- Physicochemical characteristics of synthetic resin effluent

\begin{tabular}{|c|c|c|}
\hline Parameters & $\begin{array}{c}\text { Experimental } \\
\text { Values }\end{array}$ & $\begin{array}{c}\text { FEPA } 1991 \\
\text { Specification }\end{array}$ \\
\hline $\mathrm{pH}$ & 6.7 & $6.5-8.5$ \\
\hline D.O (mg/L) & 2.6 & 5.0 \\
\hline B.O.D (mg/L) & 0.4 & 50 \\
\hline T.S.S (mg/L) & 72 & 30 \\
\hline IRON $(\mu \mathrm{g} / \mathrm{L})$ & 0.6387 & $<1.00$ \\
\hline CADMIUM $(\mu \mathrm{g} / \mathrm{L})$ & N.D & 5.00 \\
\hline CHROMIUM $(\mu \mathrm{g} / \mathrm{L})$ & 0.05 & $<1.00$ \\
\hline CYANIDE $(\mu \mathrm{g} / \mathrm{L})$ & $14 \mu \mathrm{g} / \mathrm{L}$ & 5.0 \\
\hline LEAD $(\mu \mathrm{g} / \mathrm{L})$ & 9.5765 & $<1.00$ \\
\hline COPPER $(\mu \mathrm{g} / \mathrm{L})$ & 0.0775 & $5.8-6.0$ \\
\hline ZINC $(\mu \mathrm{g} / \mathrm{L})$ & 0.3484 & $<1.00$ \\
\hline T.D.S (mg/L) & 32.4 & 2000 \\
\hline T.S (mg/L) & 3.96 & N.P \\
\hline OIL and GREASE & 12.5 & 10 \\
\hline
\end{tabular}

$\mathrm{N} . \mathrm{D}=$ not detected; NP $=$ not provided

Behavioural Responses:- During the toxicity test, Clarias gariepinus exhibited distress behavioural responses due to the effects of the synthetic resin effluent. These were noticed by the sudden change in 
the organism's response to the environment such as erratic swimming, gasping for breath and frequent surfacing which increases as the concentration increases. As the experiment progressed, the test organisms were seen to get weaker, with ventral surface turned upward and those that couldn't tolerate the concentrations any longer went into comatose. Normal behaviour were however observed in the control.

Weight Change:- At the end of the evaluation, samples were taken from all concentrations and weighed. The weight of the test organisms were found to have undergone reduction with shrinkage noticed at the head region.

Mortality:- The result of the acute toxicity shows very low mortality level in the lower concentrations while maximum mortality was observed in the highest concentration. Figure 1 shows the percentage mortality of the test organisms while (Figure 2) shows the arithmetic graph of percentage mortality against concentration for the acute evaluation. The $96-\mathrm{h} \mathrm{LC}_{50}$ was extrapolated to be $0.355187 \mathrm{mg} / \mathrm{L}$.

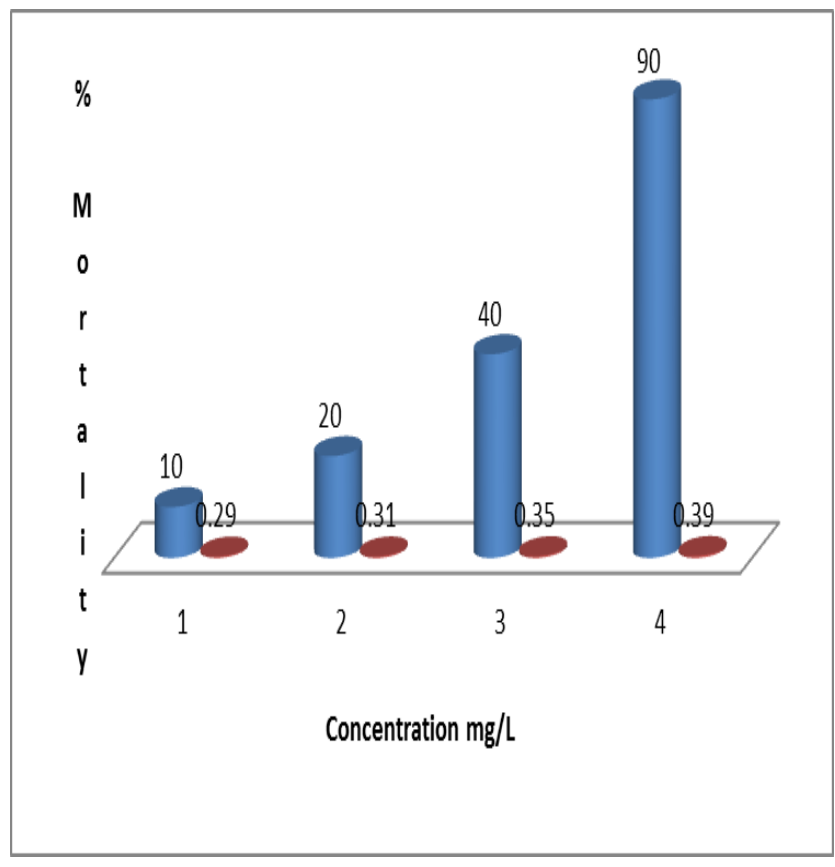

Fig 1. Percentage mortality of Clarias gariepinus exposed to lethal concentrations of synthetic resin effluent

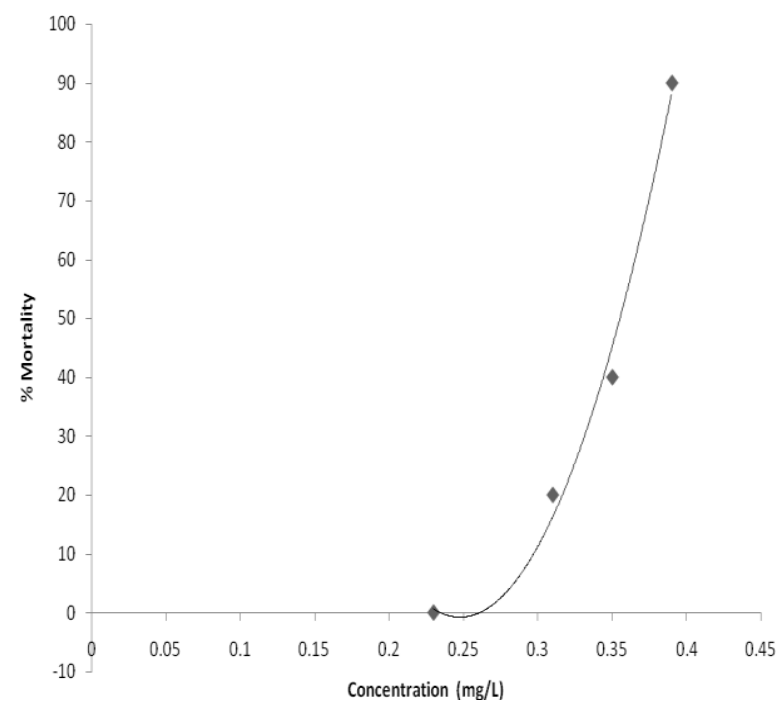

Fig 2. $\mathrm{LC}_{50}$ Determination for Clarias gariepinus exposed to lethal concentrations of synthetic resin effluent

\section{DISCUSSION:}

When organic matter content is abnormally high in an aquatic environment, the oxygen content reduces, this in turn disrupt the behavioural responses of the organisms and eventually bringing the general fitness of the natural population in that environment to the minimal. The synthetic resin effluent examined in this work was found to be high in total suspended solid (TSS), low biochemical oxygen demand (BOD), low dissolved oxygen (DO), low total dissolved solids (TDS) and high lead and cyanide content which shows the effluent to be toxic for discharge into the aquatic environment. The abnormalities observed prior to mortality is an indication of depleted oxygen content due to higher demand for oxygen, this corresponds to the findings of Adewoye et al., (2005) that the observed characteristics features may have resulted from the organic loads in the wastewater and to different concentrations of toxicants. The high degree of lead and cyanide found in the effluent may have contributed a significant synergistic effects which resulted in the breakdown of vital metabolic functions that led to high mortality observed especially in the highest concentrations and this corresponds to the discovery of Van-Dyk et al., (2007) that the harmful effects of heavy metals pollution of fish depend on the duration of the exposure (chronic or acute) and the concentration level of the specific metal.

Behavioural changes were not observed at low 
effluent concentrations, this shows that fishes tolerated low concentrations of the pollutants thus the observed reduced mortality. This corresponds to the findings of Oyedapo and Akinduyite, (2011) that when the concentration of the toxic substance is higher than what the homeiostasis of the fish can control, it result in death and cause damages in the fish opercula and may also cause physical damages to fish particularly on the skin, liver and gill surface.

The 96-h $\mathrm{LC}_{50}$ value for the acute test reported in this finding was $0.355187 \mathrm{mg} / \mathrm{L}$. This report is in tandem with the report of Kavitha et al., (2011). They observed the 96-h $\mathrm{LC}_{50}$ value of Moringa oleifera seed extract for the freshwater, Cyprinus carpio to be high $124.0 \mathrm{mg} / \mathrm{L}$. Kumar et al., (2010) reported that the $24,48,72$ and $96-\mathrm{h} \mathrm{LC}_{50}$ values of aqueous extract of Euphorbia tirucalli latex to the fish Heteropneustes fossilis was found to be $3.450 \mu \mathrm{l} / \mathrm{L}$, $2.516 \mu \mathrm{l} / \mathrm{L}, 1.623 \mu \mathrm{l} / \mathrm{L}$ and $1.315 \mu \mathrm{l} / \mathrm{L}$ respectively. Tiwari and Singh (2003) observed the toxicity of Nerium indicum leaf extract to the fish Channa punctatus and indicate that the toxicity depends on the solvent used for extraction; the $\mathrm{LC}_{50}$ value of diethylether, acetone, chloroform and methanol extract of $N$. indicum leaf extract were found to be $17.34 \mathrm{mg} / \mathrm{L}, 40.01 \mathrm{mg} / \mathrm{L}, 40.61 \mathrm{mg} / \mathrm{L}$ and $106.37 \mathrm{mg} / \mathrm{L}$, respectively. The $24-\mathrm{h} \quad L_{50}$ value of neem leaf extract for Prochilodus lineatus was found to be $4.8 \mathrm{gL}^{-1}$ (Winkaler et al., 2007). Adewoye et al., (2005) noted that at 96-h LC $_{50}$ concentration, the fitness of the natural population of an aquatic environment would be relatively impaired and as the concentration increases, the mortality rate also increases. The $96 \mathrm{~h} \mathrm{LC}_{50}$ of $0.355187 \mathrm{mg} / \mathrm{L}$ implies that at this concentration of the effluent in the aquatic environment, half of the entire natural population will become dead.

\section{CONCLUSION}

Its evident from this study that increasing concentrations of the synthetic resin effluent when present in any water body could lead to abnormal bahavioural responses and dysfunction in fish health and general condition. Hence, adequate preventive measures must be taken to prevent the indiscriminate channelling of this effluent into our water bodies having in mind that man is the ultimate target of any negative consequences resulting from such acts. Effective hazard analysis and critical control point(HACCP) monitoring is therefor advocated. Modern technologies in effluent treatment should be embraced by all stakeholders in order to maintain friendly environment and good usage of our water resources.

\section{REFERENCES}

Adewoye, S.O., Fawole, O.O., Owolabi, O.D and Omotosho, J.S (2005). Toxicity of cassava wastewater effluent to African catfish: Clarias gariepinus. Ethiop. J. Sci., 28(7): 189-1942.

Agrawal, A., Pandey, R.S and Sharma, B (2010). Water pollution with special reference to Pesticide Contamination in India. J. Water Resources and Protection. 2: 432-448.

Akhila, S.J., Deepa, S.S and Alwan, V (2007). Acute toxicity and determination of median lethal dose. Current Science. 93(7): 917-920.

Akinbulumo, M.O (2005). Derris elliptica as anaesthetic agent on Nile Tilapia, Orechromis Niloticus (Linne, 1758). Applied Tropical Agriculture, 10, Special issue: 24-27.

APHA/AWWAWEF, (1999). American Public Health Association/American Water Works Association/Water Environment Federation 19th Edition, Standard Methods for Water and Wastewater Analysis, pp 28

Ebrahinpour, M., Mosavisefat, $\mathrm{M}$ and Mohabbati, $\mathrm{V}$ (2010). Influence of water hardness on acute toxicity of copper and zinc on fish. Toxicol. Industrial Health. 6: 361-365.

FEPA, (1991). Guidelines and Standards for Environmental Pollution in Nigeria. Federal Environmental Protection Agency., 238 p.

Kavitha, C.K., Satyanarayanan, M.R and Senthil, K (2011). Toxicity of Moringa oleifera seed extract on some haematological and biochemical profiles in a freshwater fish, Cyprinus carpio. Exp. Toxicol. Pathol. (2011), doi:10.1016/j. etp.2011. 01.001.

Kumar, A., Prasad, M.R., Mishra, D., Srivastav, V and Srivastav, V (2010). Toxicity of aqueous extract of Euphorbia tirucalli latex on catfish, Heteropneustes fossilis. Ecotoxicol. Environ. Safe.,73(7):1671-3.

Mahabub-uz-zaman, M.D., Sarkar, S and Shahdat, M.D (2008). The effects of industrial effluent discharge on lipid peroxidase levels in punti fish, Puntus sophore tissue in comparison with those of freshwater fish. Journal of food lipids. 15(2):198-208.

Martin-Skiltona, R., Saborido-Rey, F and Portea, C (2008). Endocrine alteration and other biochemical response in juvenile turbot exposed to the Prestige fuel oil. Science of the Total Environment. 404: 68-76.

Mohsen, A., Gamal, O.E and, Sherien, H.H.H.S (2011). Acute Toxicity of water-born zinc in Nile Tilapia, Oreochromis niloticus (L.) fingerlings. Proceedings of the Ninth International Symposium on Tilapia in Aquaculture Shanghai, China. April 22nd-24th, 2011. 
$31-43$

Olufayo, M.O. and Jatto, I.A (2011). Haematological Response of Nile Tilapia (Oreochromis niloticus) Juvenile Exposed to Tobacco (Nicotiana tobaccum) leaf dust. Proceedings of the Ninth In ternational Symposium on Tilapia in Aquaculture. Shanghai, China. April 22nd-24th, 2011. 60-64.

Oyedapo, F., and Akinduyite, V (2011). Acute Toxicity of Aqueous Morinda lucida leaf extracts to Nile Tilapia, Oreochromis niloticus (Linnaeus, 1857). Proceedings of the Ninth In ternational Symposium on Tilapia in Aquaculture. Shanghai, China. April 22nd-24th, 2011. 52-59.

Rand, G.M., (2008). Fish toxicity studies. In:Di Giulio, R.T., Hinton, D.E (Eds.) The toxicology of fishes. CRC Press, New York, USA. Pp.659-682

Saborido-Ray, F., Dominguez-Petit, R., Thomas, J., Morales-Nin, B and Alonso-Fernandez, A (2007). Growth of juvenile turbot in response to food pellets contaminated by fuel oil from the tanker 'Prestige'.
Marine Ecology Progress Series 345:271-279.

Safaa, M.S. and Mohsen, A (2011). Eco-physiological impact of commercial petroleum fuel on Nile Tilapia, Oreochromis niloticus (L). Proceedings of the Ninth International Symposium on Tilapia in Aquaculture . Shanghai, China. April 22nd-24th, 2011. 31-43.

Tiwari, S., and Singh, V (2003). Control of common freshwater predatory fish, Channa punctatus, through Nerium indicum leaf extracts. Chemosphere. 53(8), 65-75.

Van-Dyk, J.C., Pieterse, G.M and van-Vuren, J.H.J (2007). Histological changes in liver of Oreochromis mossambicus (Cichlidae) after exposure to cadmium and zinc. Ecotoxocology and Environmental Safety. 66: $432-440$.

Winkaler E.U., Santos, T.R.M., Machado-Neto, J.G and Martinez, C.B.R (2007). Acute lethal and sublethal effects of neem leaf extract on the Neotropical freshwater fish, Prochilodus lineatus. Comp. Biochem. Physiol. 145(2): 36-44. 